\title{
Measurement of plasma fentanyl concentration: \\ COMPARISON OF \\ THREE METHODS
}

J.A. Phipps Mb Bs FFarcs, M.A. Sabourin RT BSC, W. Buckingham DIPL BlOL SCI, L. Strunin MD FFARCS FRCP(C)
The measurement of plasma fentanyl concentration by radioimmunoassay (RIA) and gas liquid chromatography (GLC) using either a flame ionization detector (FID) or nitrogen/phosphorus detector (NPD) has been compared. RIA is a satisfactory but expensive method of measuring plasma fentanyl concentration. GLC using an FID is not as satisfactory as RIA, but when an NPD is used the resulss are equal to those of RIA. In addition, other analgesics which are chemically similar to fentanyl, such as alfentanit, may also be measured by the GLC/ NPD combination using the same set of operating conditions. By contrast, an RIA method is usually specific for oniy one compound, and measurement of additional drugs would almost certainly necessitate the development of new assay kits for each one.

\section{Key words}

MEASUREMENT TECHNIQUES: gas chromatography, radioimmunoassay; ANALGESICs: fentanyl.

From the Department of Anaesthesia, University of Calgary.

Address correspondence to: Dr. L. Strunin, Department of Anaesthesia, Foothills Hospital, 1403, 29th Street N.W., Calgary, Alberta, T2N 2T9.
Fentanyl, 1-(2phenyethyl)-4-N-(N-propionyl-anilino)piperidine is a rapidly acting, highly potent synthetic narcotic analgesic, presently enjoying wide clinical application in anaesthesia. As a result of its popularity, studies requiring measurement of plasma fentanyl concentration are becoming increasingly common. ${ }^{1,2}$ Such measurement was first described by means of radioimmunosssay (RIA) ${ }^{3}$ and more recently by gas liquid chromatography using either a flame ionization detector (FID) ${ }^{4}$ or nitrogen/phosphorus detector (NPD). ${ }^{5}$ However, no comparative study of these methods has been undertaken to establish which is the most satisfactory with respect to cost, ease of performance, accuracy and reproducibility. The present paper reports such a study.

\section{Methods}

\section{Radioimmunoassay}

Samples were counted on a Packard PRIAS 400 CL/D liquid scintillation counter and the study utilized fentanyl radioimmunoassay kits (ref: FENRIA-200) produced by the Institut National des Radioélêments, Fleurus, Belgium. "Scinti-Verse" Universal LSC Cocktail (Fisher Scientific Co., New Jersey, USA) was used as the scintillation solution and Kimble "Solvent Saver" $7 \mathrm{ml}$ capacity borosilicate glass vials were used as counting vials. In addition, polystyrene assay tubes with caps (Simport Ltd., Quebec, Canada) were used.

The fentanyl standards were prepared according to the protocol specified in the RIA kit, which is based on the method described by Michiels and his colleagues. ${ }^{3}$ Each standard, control or test sample was set up in triplicate. Control samples were pre- 
TABLE I Operating conditions for flame ionization (FID) and nitrogen/phosphorus (NPD) detectors for measurement of plasma fentanyl concentration

\begin{tabular}{|c|c|c|}
\hline \multirow[b]{2}{*}{ Conditions } & \multicolumn{2}{|l|}{ Detector } \\
\hline & $F I D$ & $N P D$ \\
\hline Column & $\begin{array}{r}6 \mathrm{ft} \times 1 / 8 \text { in. i.d. } \\
\text { silanized glass }\end{array}$ & $\begin{array}{r}6 \mathrm{ft} \times 1 / 8 \text { in. i.d. } \\
\text { silanized glass }\end{array}$ \\
\hline Packing & $\begin{array}{l}3 \% \text { OV }-17 \text { on } \\
\text { Gas/Chrom Q } \\
80 / 100 \text { mesh }\end{array}$ & $\begin{array}{l}3 \% \text { OV } 17 \text { on } \\
\text { GasiChrom Q } \\
80 / 100 \text { mesh }\end{array}$ \\
\hline $\begin{array}{l}\text { Injector } \\
\text { temperature }\end{array}$ & $310^{\circ} \mathrm{C}$ & $310^{\circ} \mathrm{C}$ \\
\hline $\begin{array}{l}\text { Oven } \\
\text { temperature }\end{array}$ & $290^{\circ} \mathrm{C}$ & $290^{\circ} \mathrm{C}$ \\
\hline $\begin{array}{l}\text { Detector } \\
\text { temperature }\end{array}$ & $310^{\circ} \mathrm{C}$ & $310^{\circ} \mathrm{C}$ \\
\hline $\begin{array}{l}\text { Carrier gas flow } \\
\text { (helium) }\end{array}$ & $30 \mathrm{ml} / \mathrm{min}$ & $35 \mathrm{ml} / \mathrm{min}$ \\
\hline $\begin{array}{l}\text { Detector gas flows: } \\
\text { hydrogen } \\
\text { air }\end{array}$ & $\begin{array}{r}6 \mathrm{ml} / \mathrm{min} \\
115 \mathrm{ml} / \mathrm{min}\end{array}$ & $\begin{array}{r}3 \mathrm{ml} / \mathrm{min} \\
108 \mathrm{ml} / \mathrm{min}\end{array}$ \\
\hline
\end{tabular}

pared by introducing fentanyl citrate solution into human plasma protein fraction (Cutter Biological, Calgary, Canada) to obtain concentrations of 1,4 , $40,100,500$ and $1000 \mathrm{ng} / \mathrm{ml}$. Ten sets of samples of each concentration were analyzed and a range was established for each (mean \pm 2 standard deviations). The data obtained were used to evaluate the accuracy and precision of the subsequent test assays, which were prepared according to the protocol in the RIA kit. Following preparation and incubation, the samples were centrifuged for 15 minutes at $8000 \mathrm{~g}$. The supernatants were transferred by disposable Pasteur pipettes into $6 \mathrm{ml}$ of scintillation cocktail in the counting vials. Each sample was counted for 20 minutes at a percentage Sigma of 0.3 . The range of test samples was the same as that used for GLC (see results tables).

Gas liquid chromatography

A Perkin-Elmer Sigma 1B Gas Chromatographic System (Perkin-Elmer (Canada) Ltd.) equipped with nitrogen/phosphorus and flame ionization detectors was used. The detectors were housed in separate analyzers and the conditions for each were as shown in Table I. The voltage applied to the rubidium bead of the NPD was adjusted for maximum detector sensitivity as described in the manu- facturer's manual. Operating conditions were adjusted to give maximum component separation in minimum time. Recorder range and attenuation were set for maximum sensitivity. The area and base sensitivities used in the analysis method were calculated using a computer programme supplied by Perkin Elmer Ltd.

For the detector flames ultra high pure hydrogen and air, ultra zero gas (Matheson, Edmonton, Canada) were used. The carrier gas was ultra high pure helium (Matheson). Kimax $16 \mathrm{ml}$ culture tubes with PTFE lined caps were used. To prevent adsorption of drugs to the glass, the tubes were initially silanized with a 5 per cent solution of dimethyldichlorosilane in toluene (Eastman Kodak Co., Rochester, N.Y., USA). For both detectors the extraction solvent was 99 per cent molecular pure benzene (Fisher Scientific Co.).

Alfentanil was selected as the internal standard. A solution of $2.0 \mathrm{mcg}$ alfentanil/ml benzene was prepared using alfentanil hydrochloride powder.

All glassware was rinsed with benzene prior to use to remove interfering substances. A stock standard solution was prepared by adding $1.0 \mathrm{ml}$ of fentanyl citrate solution $(50 \mu \mathrm{g} / \mathrm{ml}$ ) to a $500 \mathrm{ml}$ volumetric flask and making up the volume with human plasma protein fraction to give a final fentanyl concentration of $100 \mathrm{ng} / \mathrm{ml} .1 .0 \mathrm{ml}$ of standard or test samples, $0.1 \mathrm{ml}$ of $4 \mathrm{~N} \mathrm{NaOH}, 5 \mathrm{ml}$ of benzene, and $1 \mathrm{ml}$ of internal standard solution were pipetted into clean culture tubes. These were sealed, mixed for one minute and centrifuged for 20 minutes, following which the supernatants were transferred to clean tubes and evaporated to dryness at $40^{\circ} \mathrm{C}$. The residues were reconstituted with $10 \mathrm{mcl}$ of benzene and $1 \mathrm{mcl}$ was injected onto the GLC columns.

Five standard samples were injected onto each column. In each case, a relative response factor for fentanyl as compared to the internal standard was calculated by the Sigma 1B computer and an average factor was then inserted into each test analysis method to allow fentanyl concentrations to be determined. The same range of concentrations of fentanyl in human plasma protein fraction as used for RIA was then prepared and, following extraction, five samples of each concentration were injected onto each column and the average fentanyl concentration determined. 
TABLE II Results of radioimmunoassay method of measurement of plasma fentanyl concentration

\begin{tabular}{lcccll}
\hline \multicolumn{7}{c}{ Concentration in $\mathrm{ng} / \mathrm{ml}$} \\
\hline Actual sample \\
$\quad$ concentration & 100 & 50 & 10 & 0.5 & 0.2 \\
Series 1 & 100 & 48 & 9.8 & 0.62 & 0.32 \\
Series 2 & 89 & 43 & 8.2 & 0.48 & 0.24 \\
Series 3 & 91 & 44 & 9.1 & 0.52 & 0.26 \\
Series 4 & 91 & 49 & 11.5 & 0.60 & 0.33 \\
Series 5 & 105 & 55 & 11.0 & 0.66 & 0.31 \\
Mean & 95.2 & 47.8 & 9.92 & 0.576 & 0.292 \\
S.D. & 6.94 & 4.77 & 1.35 & 0.07 & 0.04 \\
\hline
\end{tabular}

\section{Results}

The results are presented in Tables II to IV. Of the range of concentrations, the lowest was chosen to represent the lowest plasma fentanyl concentration it was thought possible to detect by GLC, although concentrations of as low as $30 \mathrm{pg} / \mathrm{ml}$ can be detected by RIA, ${ }^{3}$ while the highest was chosen as being the greatest likely to be encountered in most clinical applications. Over this range, there was no statistically significant difference (Student's t test) between RIA and GLC using an NPD. Using an FID, GLC was less accurate than the other methods, particularly at low concentrations.

\section{Discussion}

The ease of performance of the RIA was greatiy facilitated by the use of the RIA kits. Setting up samples for RIA was casier than for GLC, as the extractions for GLC had to be carried out with great care to ensure good drug recovery and reproducibility of results. It was found that the extraction process described by Gillespie and his colleagues ${ }^{5}$

TABLE III Results of GLC/NPD method of measurement of plasma fentanyl concentration

\begin{tabular}{lccccc}
\hline \multicolumn{6}{c}{ Conceniration in $\mathrm{ng} / \mathrm{ml}$} \\
\hline Actual sample \\
$\quad$ conccntration & 100 & 50 & 10 & 0.5 & 0.2 \\
Series 1 & 88 & 48 & 8.5 & 0.5 & 0.28 \\
Series 2 & 103 & 41 & 8.1 & 0.59 & 0.31 \\
Series 3 & 95 & 54 & 11.7 & 0.57 & 0.22 \\
Series 4 & 91 & 47 & 9.4 & 0.51 & 0.29 \\
Series 5 & 105 & 50 & 9.9 & 0.65 & 0.31 \\
Mean & 96.4 & 48 & 9.52 & 0.56 & 0.28 \\
S.D. & 7.40 & 4.74 & 1.41 & 0.05 & 0.037 \\
\hline
\end{tabular}

gave poorer drug recovery than that of Van Rooy and his colleagues, ${ }^{4}$ and was more complicated to perform. Therefore the process described by $\operatorname{Van}$ Rooy was used to evaluate the performance of both GLC detectors. Recovery of $0.2 \mathrm{ng}$ of fentanyl using this method was $75.3 \pm 4.5$ per cent, determined by injecting known concentrations of fentanyl onto the column and comparing with extracted samples. The FID is known to be some ten to fifty times less sensitive to nitrogen containing compounds than the NPD and as such was less accurate at measuring low fentanyl concentrations. This was as expected but it was felt that as the FID/GLC method is well described and still used it should be included in this study.

In order to calculate accurately low concentrations using GLC, the use of a computerised GLC system was necessary. The Sigma 1B system achieves this by measurement of peak areas, which is more accurate, particularly at low concentrations, than the measurement of peak heights described by earlier workers using less sophisticated equipment.

Preparation of samples was slightly faster for RIA, but actual sampling time was considerably faster for GLC, using either detector, with results being obtained in a few minutes. The equipment for RIA is cheaper than that for GLC. GLC has a wider application, however, being able to measure a greater variety of compounds than RIA - often using the same set of operating conditions. To measure more than one compound by RIA usually requires a different assay kit for cach compound. Thus the actual measurement of samples is significantly more expensive by RIA. Both GLC methods cost approximately the same. The NPD is more expensive to purchase but much better able to measure low concentrations of nitrogen-containing compounds such as fentanyl.

In summary, the findings indicate that the preferable method of measurement of plasma fentanyl concentration is by gas liquid chromatography with a titrogen phosphorus detector. This method is shown to be as accurate as RIA. In addition, the NPD is more versatile and more sensitive than the FID. Using a computerised system the NPD method is straightforward to set up and measurement of samples is relatively easy. We feel that the extra cost of GLC equipment is justified, as actual sampling is very much cheaper and the system has the added advantage of versatility. 
TABLE IV Results of GLC/FID method of measurement of plassma fentanyl concentration

\begin{tabular}{lccccc}
\hline \multicolumn{7}{c}{ Concentration it ng/ml } \\
\hline $\begin{array}{l}\text { Actual sample } \\
\text { concentration }\end{array}$ & 100 & 50 & 10 & 0.5 & 0.2 \\
Series 1 & 117 & 36 & 12.3 & 0.49 & 0.09 \\
Series 2 & 112 & 51 & 14.1 & 0.35 & 0.17 \\
Series 3 & 95 & 37 & 14.4 & 0.47 & 0.13 \\
Series 4 & 104 & 27 & 10.9 & 0.31 & 0.06 \\
Series 5 & 126 & 32 & 13.8 & 0.41 & 0.25 \\
Mear. & 111 & 36.6 & 13.1 & 0.41 & 0.14 \\
S.D. & 11.9 & 8.96 & 1.47 & 0.077 & 0.074 \\
\hline
\end{tabular}

\section{Acknowledgements}

The authors wish to express grateful thanks to Janssen Pharmaceutica (Canada) Ltd. for provision of the fentanyl radioimmunoassay kits and the alferttanil hydrochloride powder and to PerkinElmer (Canada) Ltd. for their help and advice. Dr. Phipps, a member of the Nuffield Department of Anaesthetics, the Radcliffe Infirmary, Oxford, England, was supported in part by a travel grant from the Wellcome Trust.

\section{References}

1 McQuay HJ, Moore RA. Paterson GMC, Adams $A P$. Plasma fentanyl concentrations and clinical observations during and after operation. $\mathrm{Br} \mathrm{J}$ Anaesth 1979; 51: 543-50.

$2 \mathrm{Hull} \mathrm{CJ}$, Bower $S$. Comparative pharmacukinetics of fentanyl and alfentanil. $\mathrm{Br} J$ Anaesth 1982; 54: 237.

3 Michiels $M$, Hendriks $R$, Heykants J. A sensitive radioimmunoassay for fentanyl. Europ J Clin Pharmacol 1977; 12: 153-8.

4 Van Rooy HH, Vermeulen NPE, Bovill JG. The assay of fentanyl and its metabolites in plasma of patients using gas chromatography with alkali flame ionization detection and gas chromatography-mass spectrometry. J Chromatography Biomedical Applications 1981; 223: 85-93.

5 Gillespie TJ, Jay Gandolfi A, Maiorino RM, Vaughan $R W$. Gas chromatographic determination of fentanyl and its analogues in human plasma. $J$ Analytical Toxicol 1981; 5: 133-7.

\section{Résumé}

On a comparé la technique pour mesurer la concentration du fentanyl dans le plasma par la méthode radio-immunologique (RIA) et la chromatographie en phase gazeuse liquide (GLC) en se servant soir d'une flamme d'ionisation détectrice (FID), soit d' un détecteur d'azote-phosphore (NPD). La méthode RIA est satisfaisante mais coûteuse pour mesurer la concentration du fentanyl dans le plasma. La méthode GLC utilisée avec la FID n'est pas aussi efficace que la méthade RIA, mais si l'on utilise le NPD on obtient les mêmes résultats qu' avec la méthade RIA. De plus, d' autres analgésiques qui sont similaires chimiquement au fentanyl, tel que l'alfentanil, peuvent aussi être mesurés en utilisant le même genre de technique. Par contre, une méthode RIA est généralement spécifique pour un seul agent. Si l'on voulait mesurer des drogucs additionnelles, chaque agent nécessiterait presque le développement d'une trousse d'essay. 